\title{
Cross-Border Arbitrage And Free Trade
}

Ralph R. Trecartin, (E-mail: rtrecart@ brockport.edu), State University of New York, Brockport Jeffrey C. Strieter, (E-mail: jstreets@ rochester.rr.com), State University of New York, Brockport

\begin{abstract}
The following study presents a theory of cross-border arbitrage by consumers. Competitive forces should explain how equilibrium prices would be set on each side of a border. Various trading partners have ratified numerous free-trade pacts. There is a need to investigate the success or failure of these agreements. Because of the many non-tariff trade barriers, it is sometimes difficult to construct meaningful tests of the free-trade issues for products on an individualized basis. Our comprehensive model of cross-border price variation develops an appropriate test. A series of hypotheses on geographical arbitrage are presented. We also explain why some products may have larger price differences than others based on price sensitive arbitrage. Our model may be used to measure the likelihood of undermining influences to free trade from any non-tariff barriers that continue to plague relations between trading partners.
\end{abstract}

\section{Introduction}

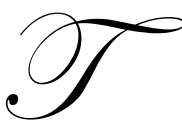

hroughout the ages, countries have sought ways to live more harmoniously with their neighbors. Negotiated trade agreements, designed with the intent of improving trade and commerce, are among the oldest accords between countries. Today, over 200 regional trade agreements have been recorded with the General Agreement on Tariffs and Trade (GATT) and the World Trade Organization

(WTO) (www.wto.org). Most countries in the world are members of one or more regional trade agreement. Recently there has been an increase in bilateral and multinational trade agreements. Free trade pacts such as the North American Free Trade Agreement (NAFTA) have been negotiated and implemented by a number of bilateral and multilateral parties. The intent of these trade agreements is to encourage and facilitate free trade for at least a portion of the commercial activities between the trading partners. These mutually beneficial agreements are designed to provide gains to each of the signatory member countries. A major issue with such an agreement is whether the goal of free and fair trade has been reached. Have these trading pacts been successful, or do tariff and non-tariff barriers still hinder the unfettered exchange of goods and services?

The ability of a trade agreement to ensure fair trade can be examined at different levels. On a large scale, a negotiated trade agreement should permit trade between the signatory parties that is more free than trade would be without the agreement. Once a trade agreement has been implemented, smaller issues, not completely defined and controlled by the trade agreement, arise. An example of this is the prices of many goods and services offered for sale in border markets. At the macro level, the trade agreement provides for the free exchange of goods and services between countries and markets. It might be expected that differences in prices in cross border markets would be smaller than if there were no trade agreement. At the micro level, there may be a number of influences affecting prices in cross border markets. If there are no barriers to trade, pressure from consumers engaging in a form of cross-border arbitrage should ensure that prices are equal, or nearly so, after adjusting for exchange rates. Product and price equality should be evident on both sides of an international border. Just as differences in prices and product offerings do exist between domestic competitors, moderate price differences are to be expected between crossborder competitors as well.

Readers with comments or questions are encouraged to contact the authors via email.

This study develops a theory that provides an upper and lower bound on these price differences. Crossborder price differences should fall within a predictable range. The theory also explains the type of consumer behavior that will likely be found in border regions. The model developed from this theory can be used to explain why 
some price differences on either side of an international border are likely to persist. If these price differences reside within the limits prescribed by the theory, they do not indicate violation of the principle of free and fair trade. The model also allows for measurement of deviations from an expected free trade price range. It also may be possible to explain why some products will be more closely aligned on the price dimension than others. Because of the many non-tariff trade barriers, it is sometimes difficult to construct meaningful tests of free-trade issues for products and services on an individualized basis. This study proposes a methodology for examining the likelihood that non-tariff barriers exist and continue to exert substantial economic effects on trade. These barriers affect prices for individual products and also for wider categories of product.

Not only can "price difference" tests be conducted for individual products, but portfolios of products and services can also be tested. For example a test of overall trade efficiency can be constructed using a market basket of goods similar to that found in the Consumer Price Index (CPI). From these tests inferences can be drawn concerning the success or failure of the particular trade pact in place on a more generalized basis. The model may be used to measure and target the undermining influences to free trade that are generated by the host of non-tariff barriers that continue to plague our relations with trading partners.

The paper is organized as follows: In Section 2 a general review of free trade agreements is undertaken. Hindrances to free trade our specified and discussed in Section 3. Cross-border consumer arbitrage is explained in Section 4. A series of hypotheses on geographical arbitrage are presented in Section 5. Price sensitive arbitrage refinements are introduced in Section 6. Finally a comprehensive model of cross-border price variation is suggested in Section 7. The paper concludes with summary remarks in Section 8.

\section{Free Trade Agreements}

On January 1, 1989 a free trade agreement was implemented between the United States and Canada. The agreement set out to eliminate most tariffs between the two countries over a 10-year phase out period ending in 1998 (Agami, 1994). The terms of this agreement, with modifications, were incorporated in the NAFTA. The three member nations of NAFTA generally agreed to eliminate the tariff barriers by removing the taxes levied on imports and to eliminate the non-tariff barriers through the abolition of import and export restrictions such as quotas and custom user fees (Fatermi and Salvatore, 1994; Zangari, 1994).

It is assumed that ten years would be sufficient for the development of an equilibrium environment for trade and trading practices. This time frame should be adequate for the governmental agencies involved to sort out the inevitable differences that arise between the trading countries. Consumers and businesses will have adjusted to the new economic conditions. The ten year period should also be sufficient time for government officials and businesses to learn ways to exploit the weaknesses and limitations of any negotiated settlement. It is under this scenario that we propose a model for testing the effects of any residual tariffs and non-tariff barriers.

Many other free trade agreements have also been established throughout the world. The model presented in this paper should be useful in analyzing those pacts currently in place. The NAFTA extended the reach of the original Canada/U.S. agreement to include Mexico. This agreement began its implementation phase on January 1, 1994. Most tariffs and non-tariff barriers were scheduled for elimination by the end of a ten-year phase-out period (Casario, 1996).

In support of the general notion of free trade, proponents present empirical evidence that documents impressive bilateral gains achieved after implementation of NAFTA. Cosario (1996) demonstrates that both the United States and Canada reaped substantial benefits from expanded trade as a result of NAFTA. Annual trade between the United States and Canada stood at \$300 billion in 1998 (Civil Engineering, 1999), up from \$100 billion in 1993 (Casario, 1996).

Peach and Adkisson (2000) present the general view held by a majority of economists concerning the benefits derived from free trade. They specify that benefits primarily accrue from cross-border commerce and a general increase in economic activity by all parties involved. Discussions concerning these benefits were undertaken at 
some length when NAFTA was implemented. Agami (1994) provides a good summary of the objectives outlined by the agreement. One of these objectives is, "to promote conditions of fair competition in the free trade area." Roberts (2000) examines a number of arguments against free-trade pacts including: the loss of jobs argument, and the unfair playing field argument. Free-trade detractors believe that free trade agreements are harmful and unfair because of non-tariff barriers and dumping activities.

While supporters and detractors of such agreements continue to disagree on the effects of free trade, there have been few attempts to actually measure the degree or level of "free" trade on any basis other than on an aggregate basis. Anderson and O'Dowd (1999) present the justification for focusing on border regions in this quest. They state that borders "are particularly revealing places for social research, especially in the present era of accelerated globalization (593). They point out that border regions are uniquely suited for investigation of cross-border arbitrage as "price advantages lurch from one side of the border to the other (594)."

Ohmae (1990) argues that the world is moving toward a borderless global economy. If the globalization of commerce has taken effect, or even if free trade is in place between some trading partners, then there should be a continual flow of goods and services across participating national borders. In this setting, price and quality differences will be relatively small assuming competition is allowed to flourish without restraint. If trade fairness issues are not addressed, many obstacles will exist to prevent product equality along the dimensions of differentiation and price. These, in turn, have a direct impact on the amount of arbitrage activity undertaken by consumers.

Thus, our motivation for examining free trade in the context of border regions comes from Anderson and O'Dowd (1999). Peach and Adkisson (2000) examine economic activity on the American side of the United States - Mexico Border. In contrast we seek to generalize the issue to the theoretical level. We specify a model and a series of tests that can be applied to any border region. Future research can then apply the theory in a more localized context.

\section{Hindrances to Free Trade}

Anderson and O'Dowd (1999) list numerous hindrances to trade including: language differences, customs procedures, legal and regulatory variation, and political instability and conflict. Despite economic integration between nations throughout the world, historical trade patterns continue to permeate global commerce. Cultural and societal differences between nations affect product tastes and needs (Cateora and Graham, 2000). Regulations and standards set at the federal and regional layers of government affect practically all goods and services that are produced and sold (Nichols and Taylor, 1995). In some instances, regulations are established that unintentionally affect free trade (Skud, 1996). Other times, governments attempt to bolster their trade terms through clever legislative acts that create barriers to imports even though tariffs have been reduced or eliminated (Hill, 2000).

Skud (1996) discusses customs requirements that are redundant, complex and cause costly time delays for the importation and transportation of goods. To some extent this type of non-tariff barrier will drive away would be competitors, allowing higher prices to be charged by domestic firms. Nichols and Taylor (1995) outline seven common non-tariff barriers. These include: 1) government support of domestic firms through purchase contracts and subsidies, 2) customs policies, 3) standards, 4) import controls, 5) non-tariff import charges, 6) foreign direct investment restrictions, and 7) weak infrastructure.

Two of the most successful trading partners in economic history are Canada and the United States. A list of documented hindrances to trade between these partners are given here as a sample of the hindrances to trade that are likely to be found between other trading partners as well.

One of the most obvious nuisances to free trade between Canada and United States results from different measurement systems. While the English measurement system dominates in the United States, the metric system is utilized throughout Canada. As a result, prepackaged goods in the United States and Canada typically contain different amounts or volumes of product. In turn, the cost differential on identical prepackaged goods in both countries may be partially attributable to the resulting differences in quantity. 
Differences in currency value may impair free trade between countries (Talaski, 2000). For example, if the exchange rate between the United States dollar and the Canadian dollar hovers around US $\$ 1.00-\mathrm{C} \$ 1.50$ for a period of time, and then moves to an exchange rate of US\$1.00 - C $\$ 1.70$, holders of United States dollars will have a greater degree of purchasing power in Canada than previously encountered. As the relative currency values change the attitudes and behaviors of consumers and business entities will also change, though differently on each side of the border.

Market size is another critical difference that curtails free trade between Canada and the United States. According to recent statistics from the U.S. Census Bureau and Statistics Canada, America has roughly 283.5 million residents while Canada has around 30.5 million residents. Due to population differences, there are thousands more retail outlets in the United States than in Canada. In turn, Canadian sales representatives are not able to generate sales volumes as large as those in the United States. As the Canadian volumes are smaller, Canadian sales vendors are sometimes prohibited from carrying more lines of goods (Agency Sales, 2000).

Special measures are taken by governments to safeguard select industries. For example, Canada and the United States impose sanitary and phytosanitary regulations to protect animals, people and plants from harmful additives, contaminants, disease-causing organisms and toxins. Exemplifying these laws, the United States recently prohibited potatoes from Prince Edward Island after learning of a harmful fungus found in a P.E.I. potato field (Tempers Flare in Potato Dispute, 2001). Another barrier that curtails the free trade of agricultural products are government control boards that influence prices. Recently the World Trade Organization (WTO) censured Canada for enforcing a dairy industry supply management scheme that shielded the Canadian dairy market from more efficient foreign producers (Jack, 2000).

Foreign relations with nations overseas affect free trade between Canada and the United States. Illustrating differences in foreign policy, Canada maintains diplomatic relations with Cuba and Iran, while the United States does not. Because Canada holds diplomatic relations with such countries, Canadian firms have a larger pool in which to procure commodities, including Cuban sugar and Iranian oil (Canada-Cuba Trade and Investment; Salam Iran). This reduces the pressure on prices for some commodities in Canada.

Product health warnings are another example of regulations that impair free trade, though perhaps rightly so. While authorities in the United States only require a sedate warning label on cigarettes, Canadian authorities require extraordinarily graphic warning labels that visually demonstrate the negative effects of smoking (New Cigarette Pack Warning Labels Appear, 2000). As the Canadian labels make a much stronger statement to smokers than American labels, cigarette sales in Canada may be at a disadvantage to American cigarette sales.

Differences in regulations between Canada and the United States at the provincial and state levels also affect free trade between the two countries. Laws pertaining to bottle deposits exemplify the effects of provincial/state level regulations on prices. While bottle deposits are not required for plastic soda bottles in Ontario for example, they are required in New York increasing the cost of carbonated beverages (Bottle Bill, 2001). Different age limits on the purchase of alcohol and tobacco products are other examples of regulations that hinder free trade. In Ontario, a consumer must be 19 to purchase alcohol and tobacco, while in New York, a consumer must be 21 to purchase alcohol and 18 to purchase tobacco (Canadian Centre on Substance Abuse, 2001).

\section{Cross-border Consumer Arbitrage}

If free trade exists between countries we should see substantial amounts of consumer activity that span both sides of a border region. Whenever differences exist in prices, and product differentiation there is an incentive for consumers to undertake cross-border commercial activities. These differences may be caused by hindrances to trade some of which have been outlined here. Whatever the reason for a price difference, arbitrage activities can be expected. It is not unusual to hear about border smuggling operations, when large price differences exist. If trade is legal, then arbitrage activities will be more subtle in nature; however, they will not be eliminated. It is these arbitrage activities that are necessary to bring trade into equilibrium on either side of a border. 
Pure arbitrage in any market can be defined as the means to earn a risk less profit. A particular security, commodity or other product is purchased in one market and simultaneously sold in another. In this way arbitrage is a useful mechanism for capturing profits as a result of differences in price. Supply and demand will be affected by this arbitrage activity putting positive price pressure on the product being purchased while putting negative pressure on the price of the product being sold. Pure arbitrage tends to push prices to equilibrium between geographically distinct markets if no structural inefficiencies are at work to perpetuate the inequality.

What is cross border consumer arbitrage? This type of arbitrage occurs when consumers travel across the border into the neighboring town, city, or region for the purpose of purchasing products or services. Consumer arbitrage is not pure arbitrage, but in general is a low risk activity if no laws are broken. Consumer arbitrage offers considerable benefits to those who engage in this type of behavior. Goods are purchased at the best price on either side of the border and then consumed over time. This is in contrast to the simultaneous sale of the product under pure arbitrage. Nevertheless, supply and demand imbalances will occur on either side of the border if prices consistently deviate from cross border alternatives. Consumers will trade the opportunity cost of time and some transportation cost or other transactions costs for the opportunity to purchase goods at lower prices or at higher quality. Business establishments that do not account for this consumer behavior will be left with slowly moving inventories on the one hand, or rapidly moving inventories but lost potential profits on the other.

An interesting example of arbitrage activities that benefit consumers at the expense of governmental revenues is the often-present tollbooth between countries as will be found at most US/Canadian border posts. One rightly assumes that tollbooths are a type of tariff, but in this context paying a reduced toll can reduce the pain of travel and increase overall economic utility. Tolls are usually set at predetermined levels and changed relatively infrequently. At the same time exchange rates are constantly fluctuating. It is thus possible for one who must commute from one country to another on a regular basis anyway, to reduce the overall level of tolls paid. This may be done by always paying the toll with the currency that best captures the deviation from the toll price ratio. If the exchange rate is C $\$ 1.50=$ US $\$ 1.00$ and the commuter has the choice of paying either $\$ 3.75 \mathrm{CA}$ or $\$ 2.25 \mathrm{US}$ (a ratio of 1.67 vs. exchange ratio of 1.50 ) then the commuter should always pay in US dollars saving $\$ 0.50$ per round trip $(\$ 3.75 \mathrm{CA} / 1.5=\$ 2.50 \mathrm{US}$ vs. $2.25 \mathrm{US}$ toll $)$ or about $\$ 125$ per average work year.

In the following sections we address the geographical issue of arbitrage. We answer the question of when arbitrage will occur, and where arbitrage will likely occur. The discussion of geographical arbitrage reveals implications regarding the efficiency of free-trade pacts.

\section{Geographical Arbitrage}

We start our discussion in this section with the following general hypothesis followed by a series of more specific hypotheses and discussion. Each hypothesis builds upon the previous one in the quest to understand crossborder price differences.

General HO: With Free and Fair Trade, Identical Product Offerings Will Be Available On Both Sides of the Border at Identical Prices.

If there are statistically significantly deviations in price between the two sides of a border, then the general hypothesis is rejected. This may imply that trade is not free or fair. Or it may be that there are alternative explanations possible. These explanations will be explored below.

As can be seen in the example presented in figure 1, under perfect price equality at a Canadian/US exchange rate of CA $\$ 1.50=$ US $\$ 1.00$ a uniform product selling for $\$ 10$ US should sell for $\$ 15$ CA. If this product were selling at $\$ 14.99 \mathrm{CA}$ it is not likely that consumers would pay much attention to the exchange rate adjusted price difference. But if the product were selling for $\$ 10.99 \mathrm{CA}$, a larger percentage of consumers than normal could be expected to purchase the product on the Canadian side of the border.

\section{Figure 1.}




\section{Retail Prices For Identical Products \\ CA $\$ 1.50 /$ US $\$ 1.00$}

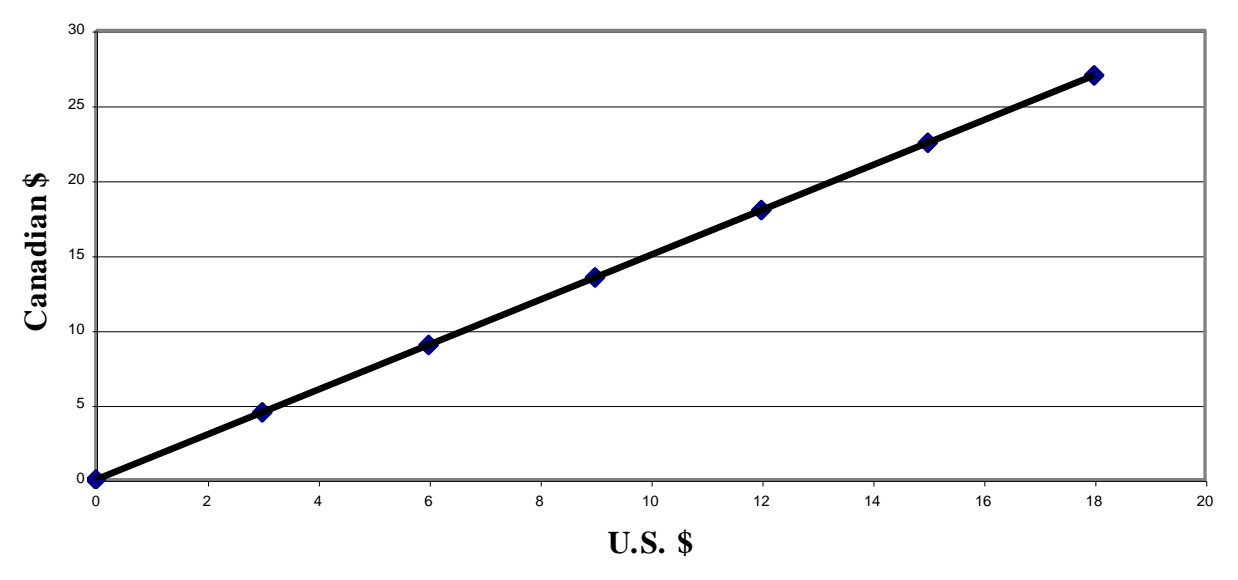

If the border in the above example were closed to consumer travel, we would expect price differences to persist. If consumers were allowed to travel, but a $20 \%$ tariff were in place for all goods brought into the US, we would also expect the price difference to persist. In general as long as certain tariff and non-tariff barriers to trade are in place, one would expect to find larger differences in price across borders. If no barriers to trade exist, large price differences should eventually evaporate.

If the general hypothesis above is tested statistically and rejected, does this mean that unfair barriers to trade exist? Not necessarily. In almost any domestic market, price differences for identical products can be found. This leads to our first specific hypothesis.

HO1: Identical Domestic Product Offerings Between Two Adjacent Retail Establishments Will Have No Variation in Price.

Rejection of this hypothesis can be demonstrated on a consistent basis if price differences are calibrated on a fairly fine level. For example, it is normal to see two gas stations located at the same intersection with a several cent difference in gasoline prices. These price differences often persist for months or years on end.

It is normal to assume some variation in prices and price differences through time. What is the cut off point between normal variation and differences in price induced by barriers to trade? One approach to measuring the incidence of "free trade" would be to measure prices on either side of a border, and assume that barriers to trade exist unless identical product offerings are found at identical prices. This is a worthy approach, and worth an empirical investigation. But, we would not expect identical prices in the domestic setting for a variety of reasons. So, why should we expect uniform prices and product offerings across borders?

In the domestic setting many reasons for differences in price can be listed that do not preclude persistent price differences over time. These include: location, convenience, impulse purchases, necessities, low priced items, near substitutes, inferior goods, human loyalty, packaging, appearance, ambiance and setting among others. If the product offering in a specific market is not identical we know that price differences will occur. Product differentiation has been documented as a useful marketing strategy in the pursuit of higher prices and larger margins.

Different pricing strategies could be used to explain persistent differences. Some businesses may use one product as a loss leader to attract customers for the purchase of other products. One store may use a "low turnover, high markup" strategy while another selling the same line of products may opt for the "high turnover, low markup approach. The gas station example above is a prime example. One station makes their profit on volume capturing a majority of the local customers. The other station will capture overflow customers who are pressed for time, and 
unwilling to wait in line at the pump. The price differences will persist because both businesses are successfully making profits using different pricing strategies.

Price differences may exist because of poor management. We would expect that a business selling products at a loss would eventually fail. But, if prices were compared before the business failure date, price differences would influence the statistical sample. In a cross border situation, we would assume that poor management would even out on each side of the border in any comprehensive sample, though other systematic differences would continue to be captured.

Competitive products across borders are more likely if free and fair trade exists. In a competitive cross border market two possibilities exist:

1. Prices and product offerings will be driven into equilibrium on either side of the border. Product offerings will be very similar if not identical.

2. For a particular product category, offerings will migrate to one side of the border or the other because of geographical advantages, such as population, demand, and other market conditions.

In summary, one would expect the rejection of HO1. Price differences are to be expected between local competitors. The real value gained from the rejection of the hypothesis, is the justification provided for the calculation of a range of prices on identical products. Once the normal range is established in the domestic setting, then it becomes helpful to project this range onto international comparisons. $\mathrm{HO} 2$, is useful in this regard.

HO2: Identical Domestic Product Offerings Between Two Adjacent Retail Establishments Will Not Diverge From Each Other Beyond Some Percentage Difference (Delta).

$\mathrm{Pa}=\mathrm{Pb}+/-\delta$

$\mathrm{Pa}=$ Price of firm a's product

$\mathrm{Pb}=$ Price of firm b's product

$\delta=$ Price difference between "a" and "b"

In the gas station example above, the normal price difference for a gallon of gas at $\$ 1.55$ vs. $\$ 1.57$ per gallon would be $\$ 0.02$. Since price changes between the two gas stations may not be simultaneously executed, and because the variation in prices over time may not be constant, it would be possible to use the standard deviation of price differences to help determine an appropriate delta. In this case we could assume a higher delta for our standard, (delta $=\$ 0.03$ or about $2 \%$ price difference).

Rejection of $\mathrm{HO} 2$ for any given delta simply implies that a wider distribution of price bounds is necessary in order to capture the free trade upper and lower limits on price that can be expected in a setting of domestic competition. HO3 adds an additional factor to the consideration of what delta should be.

HO3: The Normal Delta Will Not Be Affected by Geographical Distance Between Firms.

Rejection of this hypothesis is to be expected because of various types of "transactions costs." It takes more time, and is more expensive to drive across town to make a purchase. Thus some businesses will charge higher prices but capture revenues based on convenience or the "reduced transactions cost" to the consumer. Transaction costs can be real (feed the parking meter) or psychological (it is too hot to get a better price).

By including distance in the analysis of an acceptable range of prices between competitors, it is possible to establish adjustable free trade bounds that more accurately capture normal price variation. Price differences between firms in adjacent domestic cities can be expected to be larger than differences between firms in more close proximity. When venturing to analyze price differences on either side of a border, the distance adjusted domestic delta needs to be considered. 
In an environment of free trade such as between states in the U.S, price differences between cities on each side of a state border will be bounded by $\delta+\varepsilon$.

$\varepsilon=$ Differences in state taxes and regulations.

If one state has a $6 \%$ sales tax while the other a 5\% sales tax, cross "state" border arbitrage is expected to keep product prices within a comparable range, but not identical.

$\mathrm{Pa}=\mathrm{Pb}+/-(\delta+\varepsilon)$

HO4: Given Adjacent Cities on Either Side of a Country Border, Prices Will Diverge at Most by $(\delta+\varepsilon)$.

Rejection of this hypothesis provides a somewhat stronger indication of trade barriers than rejection of the original general hypothesis above. By allowing prices to diverge within a particular bound, normally occurring price differences are not used to prejudice a judgment of fairness.

In an empirical study on a particular product it would be necessary to establish the normal $\delta$ in percentage terms. Special care would be necessary to determine the geographical distance between border towns and apply that distance in one or more domestic marketplaces when calculating $\delta$. When estimating eactual tax differences between the two countries may be used. An alternative approach is to estimate a domestic $\varepsilon$ between two or more domestic cities on either side of a state border, and then simply apply this $\varepsilon$ in the international setting.

For some products an actual tax $\varepsilon$ estimation procedure may be misleading. For example taxes applied to the purchase of an automobile may be very different between two states or countries, but the procedures for registration may require the domestic tax rate to be applied no matter where the purchase took place. Smaller consumer products may not face this problem.

If non-tariff barriers are exerting an undue influence on international trade it is likely that product prices will diverge by more than $(\delta+\varepsilon)$. By testing $\mathrm{HO} 4$, a rejection indicates some non-tariff barriers are probably at work.

In order to fully explain cross-border arbitrage, it may be useful to compare prices on either side of a border with striations of geographical distance. By examining price differences immediately next to the border on each side, and then comparing these differences to prices set at a considerable distance from the border on each side, we can better evaluate the success or failure of consumer arbitrage to drive prices in a localized geographical equilibrium.

HO5: Geographical distance between a city and a border will have no effect on price differences.

One would expect that the farther a city is located geographically from the border, the wider the divergence in price allowed to compensate for transactions costs of arbitrage such as transportation costs and information barriers (where to shop on the other side of the border). This hypothesis is similar to HO3 above. Whereas HO3 examines price differences between domestic firms separated by distance, HO5 examines the effect of geographical distance on product prices on either side of a border.

One would assume that consumers would be more apt to make purchases on the other side of the border if the distance is small. Thus a city close to the border should exhibit more price similarity with prices on the other side of the border, then with a city that is some distance "inland." The city not exposed to border arbitrage, is likely to have less pressure on prices from this type of activity.

\section{Price Sensitive Arbitrage}


Given the above discussion on geographical arbitrage we assume that there may be moderate if not substantial price differences between identical products sold on different sides of an international border. If these prices fall within a reasonable upper and lower bound we cannot reject the notion of free and fair trade. But, if these prices fall outside this bound we have evidence to support the "barriers to trade" argument.

Up to this point we have not suggested whether the bounds are uniform across products, or whether the bounds vary from product to product in any sort of systematic fashion. It is even possible that price variation is random. To test this issue we suggest the following general hypothesis.

General HO: All products will exhibit an identical band of price variation, i.e. All product prices will be bounded by the same $\%$ difference

Four outcome scenarios are likely when this hypothesis is tested. The first of these scenarios assumes that the hypothesis cannot be rejected. The other three scenarios each contribute to an explanation of price variation that may be found even in the event of free and fair trade. These scenarios are listed here:

1. Constant percentage price range across products.

2. Linear percentage differences in price - low to high.

3. Linear percentage differences in price - high to low.

4. Curvilinear differences in price.

If the general hypothesis cannot be rejected, it then becomes fairly easy to construct generalized tests of free trade efficiency across a portfolio of products. If a substantial percentage of items in the portfolio demonstrate prices that fall outside the $(\delta+\varepsilon)$ bound, it is reasonable to conclude that some barriers to trade are hurting trade efficiency.

If scenario two turns out to be more accurate, low price products will exhibit low percentage differences, and high priced products will exhibit high percentage differences. If scenario three represents reality, the reverse is true. High price products will exhibit low percentage differences, and low priced products will exhibit high percentage differences.

We suggest that scenario four is the most likely if free trade agreements are in place and yet non-tariff barriers are at work. Low priced products will have large percentage differences on either side of a border, because consumers will not be bothered on average to shop for the best price when the absolute price difference is lower than the real or perceived transaction cost of crossing the border. By estimating a $(\delta+\varepsilon)$ bound for low priced products in the domestic setting it is then possible to test whether the hassles of cross border shopping are increasing price differences. One criticism of this suggestion is that consumers may still benefit by crossing the border to purchase many small priced items at one time, thus diluting the larger percentage price difference argument.

Under the fourth scenario, moderately priced items will exhibit the smallest percentage price differences, because consumer arbitrage becomes an economical activity. Consumers will push prices close to or within the $(\delta+$ $\varepsilon$ ) bound as supply and demand are equalized by competitive forces.

High priced items, provide the incentive for consumer arbitrage, but also provide larger incentives for merchants and governments to enter into protectionist activities. Thus it may be expected that these items again will exhibit price differences that are larger in percentage terms than for those found on medium priced merchandise.

Whether the $(\delta+\varepsilon)$ bound in the domestic setting is higher for high priced items is not known. It is likely that issues of trust, reliability, and reputation become much more important with the increased monetary outlay for these products. These issues in turn provide for important factors in product differentiation and should enable larger price differences between competitors. Because the remedy for any breach of trust is likely to be more complicated in international trade, it is not unreasonable to assume that high priced items will fall substantially outside of the domestic $(\delta+\varepsilon)$ bound. Figure 2 graphically portrays this scenario. 


\section{Cross Border Model}

Halat and Trecartin (2001) examine price differences for a sample of products in the cities of Niagara Falls, Canada and Niagara Falls, New York. Table 1 provides a list of these differences after adjusting for exchange rates. For some products, including flour, off-brand jeans and dog food, the differences between Canadian and American prices are small. The local newspapers were priced the same in both market places. On the other hand, significant price differences are found for Coca-Cola, fuel oil, eyeglasses and cigarettes. We conclude that price equilibrium in the cross border markets does exist for some products and does not exist for other products.

The following model is proposed as a means to explain price differences across borders. The model predicts that normal price variation in the domestic market will contribute information on the magnitude of price differences across borders. The sign of this variable is expected to be positive. Tax differences and geographical distance should also positively impact the cross border price range. The product price level may be positively or negatively related to cross border price differences in a linear fashion as is captured by equation (3). Or, as in equation (4) curvilinear price differences may be captured by the use of dummy variables for low and moderate product price segments.

The following model is proposed as a means to explain price differences across borders. The model predicts that normal price variation in the domestic market will contribute information on the magnitude of price differences across borders. The sign of this variable is expected to be positive. Tax differences and geographical distance should also positively impact the cross border price range. The product price level may be positively or negatively related to cross border price differences in a linear fashion as is captured by equation (3). Or, as in equation (4) curvilinear price differences may be captured by the use of dummy variables for low and moderate product price segments.

Figure 2

\section{Retail Prices For Identical Products CA $\$ 1.50 /$ US $\$ 1.00$}

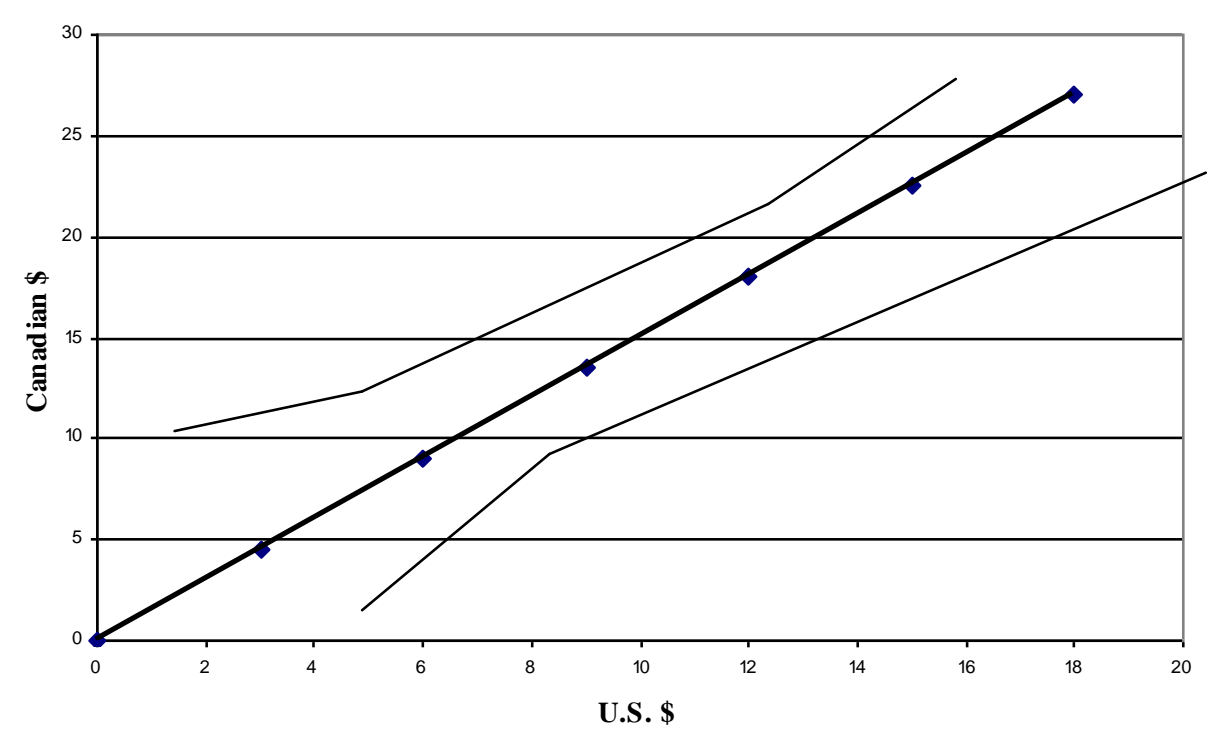

Table 1

Comparative Overview of the Market Baskets 


\begin{tabular}{|c|c|c|c|c|c|}
\hline Item Used In The Study & $\begin{array}{c}\text { Origin: Cana- } \\
\text { dian Market } \\
\text { Basket } \\
\end{array}$ & $\begin{array}{c}\text { Origin: } \\
\text { American } \\
\text { Market Basket }\end{array}$ & $\begin{array}{c}\text { Product Cost: } \\
\text { Canadian } \\
\text { Market Basket }\end{array}$ & $\begin{array}{c}\text { Product Cost: } \\
\text { American } \\
\text { Market Basket }\end{array}$ & \begin{tabular}{|c|} 
Difference \\
Between \\
Canadian \& \\
American Costs \\
\end{tabular} \\
\hline Robin Hood All Purpose Flour & Canada & U.S.A. & 1.98 & 1.89 & $5 \%$ \\
\hline Lean Ground Beef (1 Kg) & $\mathrm{n} / \mathrm{a}$ & $\mathrm{n} / \mathrm{a}$ & 2.92 & 2.49 & $15 \%$ \\
\hline $2 \%$ Milk & Canada & U.S.A. & 1.68 & 1.51 & $10 \%$ \\
\hline Red Delicious Apples (1 Kg) & U.S.A. & U.S.A. & 1.45 & 0.99 & $32 \%$ \\
\hline Coca-Cola (2 Liters) & Canada & U.S.A. & 0.78 & 1.50 & $-92 \%$ \\
\hline Sugar & Canada & U.S.A. & 1.27 & 2.39 & $-88 \%$ \\
\hline Mc Donalds "Big Mac" Sandwich & Canada & U.S.A. & 1.92 & 2.15 & $-12 \%$ \\
\hline Budweiser 6-Pack & Canada & U.S.A. & 6.18 & 4.99 & $19 \%$ \\
\hline Hampton Inn (1 Night Stay) & Canada & U.S.A. & 48.95 & 59.00 & $-21 \%$ \\
\hline Fuel Oil & $\mathrm{n} / \mathrm{a}$ & $\mathrm{n} / \mathrm{a}$ & 0.952 & 1.499 & $-57 \%$ \\
\hline Designed Floor Covering & U.S.A. & U.S.A. & 99.70 & 79.99 & $20 \%$ \\
\hline White Wall Clock & U.S.A. & U.S.A. & 7.31 & 5.49 & $25 \%$ \\
\hline Fruit of the Loom Sweatpants & Mexico & Mexico & 7.97 & 6.99 & $12 \%$ \\
\hline Off-brand Jeans (Size 10) & China & Mexico & 13.27 & 12.99 & $2 \%$ \\
\hline Men's Off-brand Sneakers (Size 10) & China & China & 26.58 & 19.99 & $25 \%$ \\
\hline 2001 Buick LeSabre Custom Sedan & U.S.A. & U.S.A. & 21350.70 & 24762.00 & $-16 \%$ \\
\hline 2 Hour Train Ride & Canada & U.S.A. & 18.49 & 26.00 & $-41 \%$ \\
\hline Hydrogen Peroxide $(500 \mathrm{ml})$ & Canada & U.S.A. & 0.62 & 0.44 & $29 \%$ \\
\hline Eyeglasses (1.25x strength) & China & U.S.A. & 9.29 & 17.99 & $-94 \%$ \\
\hline RCA 13" Color Television & Thailand & Thailand & 132.94 & 119.99 & $10 \%$ \\
\hline Dog Food & Canada & U.S.A. & 5.50 & 4.99 & $9 \%$ \\
\hline Off-brand Basketball & China & Malaysia & 3.30 & 4.99 & $-51 \%$ \\
\hline Kodak Gold 35mm film, 24-exposure & U.S.A. & U.S.A. & 2.92 & 1.98 & $32 \%$ \\
\hline Monopoly Game & U.S.A. & U.S.A. & 12.61 & 7.88 & $38 \%$ \\
\hline Blockbuster Video, 24 hour rental & Canada & U.S.A. & 3.66 & 4.06 & $-11 \%$ \\
\hline Golden Books, "Math 1-2" & U.S.A. & U.S.A. & 3.16 & 2.09 & $34 \%$ \\
\hline Local Newspaper & Canada & U.S.A. & 0.50 & 0.50 & $0 \%$ \\
\hline Local Mail, 1 Letter & Canada & U.S.A. & 0.31 & 0.34 & $-10 \%$ \\
\hline Payphone, Local Call & Canada & U.S.A. & 0.17 & 0.25 & $-47 \%$ \\
\hline "Wheel of Fortune," Computer Game & U.S.A. & U.S.A. & 23.26 & 29.95 & $-29 \%$ \\
\hline Cigarettes (20-pack) & Canada & U.S.A. & 2.41 & 4.96 & $-106 \%$ \\
\hline Head \& Shoulders Shampoo & U.S.A. & U.S.A. & 3.42 & 2.69 & $21 \%$ \\
\hline Shirt Cleaning & Canada & U.S.A. & 2.33 & 1.20 & $48 \%$ \\
\hline Writing Tablet (100 Sheets) & Canada & Indonesia & 0.99 & 1.49 & $-51 \%$ \\
\hline
\end{tabular}

$\mathrm{PPD}=\alpha+\delta \mathrm{X} 1+\varepsilon \mathrm{X} 2+\mathrm{DX} 3+\mathrm{PX} 4+v$

PPD $=$ Price Percentage Difference

$\delta=$ Domestic Price Difference

$\varepsilon=$ State or Country Tax Difference

$\mathrm{D}=$ Distance from Border

$\mathrm{P}=$ Product Price Level

$\mathrm{v}=$ Residual 


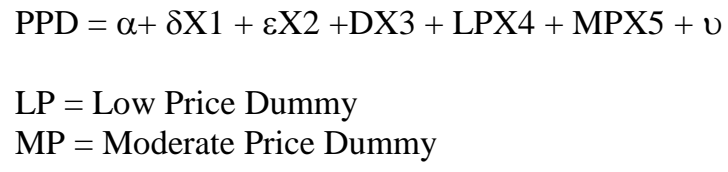

In the discussion of price sensitive arbitrage it was suggested that low and high price level products would both have larger percentage price differences than moderate price level products. If low price level products have higher percentage price differences than moderately priced products, than LPX4 in the model will have a statistically significant positive sign. The variable MPX5 would be expected to have an insignificant role in the model or alternatively to exhibit a significant and negative sign according to the theory presented earlier. The intercept captures the effect of high price products. If barriers to trade are systematically causing prices to diverge in border commerce, these effects will be captured in the residuals of the model.

\section{Implications}

Where there is no free trade, it is typical to find large price differences for similar products on either side of an international border. Where free trade does exist, there are much smaller price differences. This paper posits cross border arbitrage as a valid tool for examining these differences. The magnitude of price differences can be used as a surrogate measure for the effectiveness of free trade.

This paper develops a theoretical model of cross border arbitrage. The model can be used to determine a free-trade range of prices. If the price differences are small (and therefore within the free-trade range), one may assume that free trade is effective. When the price differences are large (outside the free-trade range), we can conclude that barriers to free trade may exist. The model contains variables that explain the free trade range of prices. The variables include domestic price difference, state or country tax difference, distance from border and product price level.

Free trade agreements are traditionally structured and examined on a macro basis. Once implemented, the agreements are interpreted and utilized on a micro basis by trade officials, businesses and consumers. As an indicator of free trade effectiveness, cross border arbitrage is useful for measuring the price differences between two countries. Countries should be interested in measuring this effectiveness for two reasons:

1. Countries individually need to measure and monitor the affect free trade agreements have on its citizens. In those situations where unanticipated, negative impacts do occur, governments must intercede to minimize these impacts on select markets.

2. When the negative impacts of an agreement become significant, they become the driving force to modify the current agreement or negotiate a new agreement between the two partners.

\section{Suggestions for Future Research}

1. The hypothesized model should be tested empirically with data gathered from appropriate cross border geographic settings.

2. Once the model has been tested, further development might result in the ability to examine differences in prices based upon shopping behavior and purchase importance.

3. The model may also be useful in developing more understanding of the causal behavior of illegal forms of commerce (smuggling), which develop as a result of trade agreements.

\section{References}

1. Agami, A. M., Rules of Origin Under NAFTA. Multinational Business Review. Fall 1994.

2. Anderson, J. and O’Dowd, L., Borders, Border Regions and Territoriality: Contradictory Meanings, Changing Significance. Regional Studies Association, Vol 33.7; 1999. 
3. Bottle Bill. Official Website of the Container Recycling Institute. Available: www.bottlebill.org

4. Canada-Cuba Trade and Investment. Department of Foreign Affairs \& International Trade, Country Information: Cuba. Available: www.dfait-maeci.gc.ca/latinamerica/cubatrade-e.asp

5. Canadian Centre on Substance Abuse. Official Website. Available: www.ccsa.ca

6. Casario, M., North American Free Trade Agreement Bilateral Trade Effects. Contemporary Economic Policy, Vol. XIV; January 1996.

7. Cateora, P. and Graham, J., International Marketing. McGraw-Hill; July 2000.

8. Fatermi, K., and Salvatore, D., The North American Free Trade Agreement. Tarrytown: Elsevies' Science, 1994.

9. Halat, N., and Trecartin, R., Tale of Two Cities: Examining Free Trade in the Context of Niagara Falls, Canada \& Niagara Falls, U.S.A. Proceedings of the National Conference on Undergraduate Research (NCUR 2001). University of Kentucky, March 15-17, 2001, Lexington Kentucky.

10. Hill, C., Competing in the Global Marketplace. McGraw-Hill; June 2000.

11. Jack, I., WTO review positive, but hits hairy tariffs: some more than $300 \%$. Ottawa perpetuating inefficiencies at the cost of consumers. Financial Post: 16 Dec. 2000.

12. NAFTA Traffic Drives Border and Corridor Transportation Grants. Civil Engineering, September 1999.

13. New cigarette pack warning labels appear. Official Website of Health Canada. Available: www.hcsc.gc.ca/english/archives/releases/2000/2000_21_tob-label.htm.

14. Nichols, E.L. and Taylor, J.C., Sourcing Implications of the North American Free Trade Agreement. National Association of Purchasing Management Inc., April 1995.

15. Ohmae, K., The Borderless World. Collins, London, 1990.

16. Peach, J.T. and Adkisson, R.V., NAFTA and Economic Activity Along the U.S.-Mexico Border. Journal of Economic Issues. Vol XXXIV, No. 2; June 2000.

17. Roberts, R., Speaking About Trade to the Open-Minded Skeptic. Cato Journal, Vol. 19, No. 3 (Winter 2000).

18. Salam Iran. Official Website of the Embassy of the Islamic Republic of Iran, Ottawa. Available: www.salamiran.org.

19. Skud, T., Customs Procedures as the Residual Barriers to Trade. Law and Policy in International Business, Washington, Summer, 1996.

20. Talaski, K., Canadian exchange saves U.S. shoppers. Detroit News, 13 Oct. 2000.

21. Tempers flare in potato dispute, Canada sees trade barrier in U.S. move to contain fungus outbreak. The Boston Globe: 6 January 2001.

22. U.S.-Canadian differences noted. Agency Sales, May 2000.

23. World Trade Organization. Official Website. Available: www.wto.org.

24. Zangari, B.J. (ed.), 1994. NAFTA: Issues, Industry Sector Profiles, and Bibliography. Commack: Nova Science Publishers Inc. 